\title{
PERAN HUBUNGAN MASYARAKAT (HUMAS) DALAM PENGELOLAAN LAYANAN INFORMASI E-GOVERNMENT DI KANTOR KEMENTERIAN AGAMA KABUPATEN GRESIK
}

\author{
Dalilah Ayu Permatasari, Irsyadatun Ni'mah Almatin, Wiladatus \\ Sholihah, Ali Mustofa \\ UIN Sunan Ampel, Surabaya - Indonesia I ayups2120@gmail.com
}

\begin{abstract}
Abstrak: Public relations in an organization aims to create a positive image of the organization in public. Government public relations provide services, disseminate information and provide education to the public regarding policies and institutional work programs for the public. Management of information services can be accessed through social media, one of which is the website. Egovernment is an activity carried out by the government using information technology support in providing services to the community. The purpose of this study was to determine the role of public relations in managing e-government information at the Office of the Ministry of Religion, Gresik Regency. This study used a qualitative descriptive research method with a phenomenological approach, while the informants of this study were the Gresik Ministry of Religion's public relations officers. Data collection techniques were carried out by observation, interviews and documentation. Based on the results of data reduction, the results of this study indicate that the role of public relations in the management of e-government information services at the Office of the Ministry of Religion of Gresik Regency has not been implemented optimally.
\end{abstract}

Keywords: public relations, information services, e-government.

\section{Pemdahuluan}

Perkembangan teknologi yang semakin pesat membuat masyarakat semakin mudah dalam mendapatkan informasi, oleh karenanya Public Relations harus siap menghadapi berbagai perubahan dengan menyesuaikan perkembangan media baru (Purworini, 2014). Salah satu teknologi yang berkembang yaitu teknologi berbasis internet. Internet menjadi media yang sangat 
penting untuk mendukung kemajuan dan perkembangan dalam menyampaikan informasi kepada masyarakat serta menjadi alat komunikasi yang cepat, tepat, efektif, dan efisien. Sesuai dengan kondisi saat ini, pemerintah menekankan pemanfaatan teknlogi informasi dalam menunjang aktivitas kegiatan pemerintahan. Adanya media sosial saat ini diharapkan mampu memberikan peluang pada pemerintahan untuk menyampaikan dan melayani publik. Peningkatkan partisipasi publik dapat dilakukan dengan cara membangun komunikasi dua arah yang efektif dengan masyarakat, salah satunya melalui media sosial. Media sosial yang bisa di gunakan yaitu twitter, facebook, youtube, instagram dan lain sebagainya.

Media sosial mudah digunakan oleh karyawan dan masyarakat serta mudah dalam melakukan aktivitas interaktif melalui audio vidio dan lainnya tanpa harus mengeluarkan biaya yang mahal (Purworini, 2014). Pemerintah Indonesia melalui Kementerian Agama telah menyiapkan langkah strategis melalui web https://kemenag.go.id/ dengan tujuan untuk mendorong angkatan kerja di Indonesia terus belajar dan meningkatkan keterampilan dalam memahami teknologi internet. Implementasi pengunaan teknologi informasi dan komunikasi dalam pemerintahan yakni dengan adanya E-Government (egov). Perkembangan teknologi informasi dan komunikasi tersebut harus diimbangi dengan peluang dan tantangan yang perlu untuk diantisipasi agar dapat dimanfaatkan dengan mudah untuk kesejahteraan masyarakat.

Kementerian Pendayagunaan Aparatur Negara dan Reformasi Birokrasi Republik Indonesia Tahun 2011 merancang mengenai Pedoman Umum Tata Kelola Kehumasan di Lingkungan Instansi Pemerintah tentang misi praktisi humas pemerintah yaitu membangun citra dan reputasi positif Humas pemerintah sebagai salah satu aparatur negara, membentuk opini publik, menampung dan mengolah pesan serta aspirasi masyarakat, mengklarifikasi data dan informasi yang berkembang di masyarakat, hingga mensosialisasikan kebijakan dan program pemerintah (purworini, 2014). 
Hubungan masyarakat dalam instansi sangat penting sebagai penyampaian informasi dari pemerintah kepada publik yang berkaitan degan kegiatan maupun kebijaksanaan pemerintah. Menurut Onong Uchjana Effendy, Humas pemerintahan memiliki dua tugas, yaitu menyebarkan informasi secara teratur mengenai kebijaksanaan, perencanaan dan hasil yang telah tercapai serta menerangkan dan mendidik publik mengenai perundangundangan dan hal-hal yang bersangkutan dengan kehidupan masyarakat sehari-hari.

Adapun tugas kehumasan pemerintah menurut Susanto, yaitu : (1) tugas strategis Humas yakni ikut serta dalam poses pengambilan keputusan, (2) tugas taktis yakni memberikan informasi, motivasi, dan menjalankan komunikasi timbal balik sehingga membuat citra baik. Tugas taktis Humas juga diartikan mengamankan kebijaksanaan pemerintah agar dapat menjalankan tugas taktis dengan baik. Selain itu, Humas pemerintahan juga memilki tujuan yang harus dicapai, yaitu: (1) mempertahankan hubungan baik antar instansi, (2) memberikan keterangan agar masyarakat mengetahui apa yang akan dilakukan oleh instansi pemerintah.

Untuk mencapai tujuannya, humas pemerintah diharapkan mampu menjalankan fungsi-fungsinya antara lain: (1) mengimplementasikan kebijaksanaan publik, (2) membantu media dalam memberitakan pemerintah, (3) melaporkan pada publik mengenai aktivitas organisasi, (4) meningkatkan kebersamaan dalam organisasi, (5) meningkatkan sensivitas organisasi terhadap publiknya, (6) memberikan dorongan kepada organisasi. (Diah Anggrahini, Rochayanti, \& Arif Sosiawan, 2008)

Humas berfungsi sebagai tempat keluar masuknya informasi dari dan untuk masyarakat, dapat juga dikatakan sebagai jembatan penghubung antara pemerintah dan masyarakat. Dari berbagai informasi dan masukan dari masyarakat di serap oleh humas dan di sampaikan kepada pimpinan selaku penentu kebijakan.

Misi kehumasan pemerintah sangat peting dilakukan untuk mengetahui sikap praktisi kehumasan pemerintah terhadap media.

Pemerintah berkewajiban untuk menyampaikan informasi publik yang di butuhkan oleh masyarakat, yang mana sejalan 
dengan pengembangan demokratisasi dalam berbangsa dan bernegara. Hal ini masyarakat ingin mendapatkan pelayanan publik yang maksimal sehingga diperlukan media yang mudah diakses.

Teknologi informasi dan komunikasi yang semakin maju di bidang pemerintahan diwujudkan dengan sebuah sistem yang disebut dengan e-government atau elektonik government. Egovernment dapat diartikan sebagai aplikasi berbasis komputer dan internet yang digunakan untuk meningkatkan hubungan dan layanan pemerintah kepada warga dan masyarakatnya.

Secara sederhana, e-government atau pemerintahan digital adalah kegiatan yang dilakukan oleh pemerintah dengan menggunakan dukungan teknologi informasi dalam memberikan layanan kepada masyarakat (Hasibuan dan Santoso, 2005). Pentingnya e- government ini antara lain: (1) mendorong pemerintahan yang responsif terhadap kebutuhan dan aspirasi masyarakat; (2) mendorong sisi pemanfaatan dari keterbukaan informasi dan (3) mendorong tingkat partisipasi publik didalam sistem penyelenggaraan pemerintahan.

E-government sangat berperan dalam meningkatkan kualitas pelayanan publik serta membantu proses penyampaian informasi yang lebih efektif kepada masyarakat. Perlu disadari dan dipahami bahwa sesuai amanat UUD 1945 Pasal 18 ayat (2) dan Pasal 34 ayat (3), maka peningkatan pelayanan publik (public service) harus mendapatkan perhatian utama dari pemerintah, karena pelayanan publik merupakan hak-hak sosial dasar dari masyarakat (social rights) ataupun hak yang mendasar (fundamental rights) (Elysia, Wihadanto, \& Sumartono).

Pengembangan e-goverment bertujuan untuk memfasilitasi pengguna internet agar dapat mengakses informasi terkait pelayanan pemerintahan. Menurut kasiyanto secara umum konsep e-goverment dapat didefinisikan sebagai bentuk penerapan teknologi eloktronik dalam berbagai kegiatan pemerintahan baik yang mencangkup internal maupun eksternal untuk pencapian kinerja yang efektif, efisien, cepat dan transparan. Sedangkat menurut Seifart dan Bonham mengatakan bahwa implementasi dari e-goverment dapat memberikan beberapa keuntungan baik secara 
langsung maupun tidak. Keuntungan tersebut dapat dilihat dari "E" dalam konsep e-goverment efisiensi, efektivitas dan ekonomi (kusuma habibie, 2019).

Berangkat dari beberapa pemaparan di atas penelitian ini berfokus pada peran humas dalam pengelolaan layanan informasi e-government. Maka, penelitian yang akan dilakukan berjudul Peran Humas dalam Pengelolaan layanan Informasi E-Government di Kantor Kementerian Agama Kabupaten Gresik.

Berdasarkan pemaparan diatas maka rumusan masalahnya "Bagaimana peran humas di Kantor Kemeterian Agama Kabupaten Gresik?". Sedangkan rumusan masalah khususnya: (a) Bagaimana peran humas terhadap pengelolaan layanan informasi di Kantor Kemeterian Agama Kabupaten Gresik?; (b) Bagaimana layanan informasi e- government di Kantor Kementerian Agama Kabupaten Gresik?

Tujuan dari penelitian ini untuk mengetahui Peran Humas dalam Pengelolaan Layanan Informasi E-Government di Kantor Kementerian Agama Kabupaten Gresik. Sedangkan manfaat dari penelitian ini unuk memperoleh informasi mengenai Peran Humas dalam Pengelolaan Layanan Informasi E-Government di Kantor Kementerian Agama Kabupaten Gresik.

\section{Metodologi}

Motodologi penelitian merupakan langkah yang dimiliki dan dilakukan oleh peneliti dalam rangka mengumpulkan data dan informasi. Metodologi penelitian memberikan gambaran dari rancangan penelitian yang meliputi prosedur, langkah- langkah yang harus ditempuh, waktu penelitian, sumber data dan informasi yang diperoleh, kemudian diolah dan dianalisis. Penulis harus memahmi dengan benar metode yang akan digunakan guna memenuhi segala aspek data yang nantinya akan digunakan (J. Moleong, 2008). Penelitian ini dilaksanakan pada bulan Oktober di Kantor Kementerian Agama Kabupaten Gresik. Informan penelitian ini yaitu Pranata Humas Kemenag Gresik.

Penelitian ini menggunakan metode penelitian deskriptif kualitatif dengan pendekatan fenomenologi, yang mana berfokus 
pada penggambaran kondisi suatu objek atau fenomena tertentu berdasarkan fakta empiris untuk selanjutnya disimpulkan sebagaimana realitas yang ada. Deskriptif adalah suatu tindakan untuk menggambarkan variabel satu per satu. Penelitian ini ditunjukan untuk mengumpulkan informasi secara rinci yang menggambarkan gejala yang ada, mengidentifikasi masalah atau memeriksa kondisi dan praktik yang berlaku, membuat perbandingan dan evaluasi, menentukan apa yang dilakukan orang lain dalam menghadapi masalah yang sama dan belajar dari pengalaman untuk menetapkan keputusan dan rencana yang akan datang. Maka metode penelitian kualitatif deskriptif merupakan penelitian yang berfokus pada suatu fenomena terperinci melalui teknik wawancara, observasi dan studi kepustakaan (Rakhmat, 2012) Teknik pengumpulan data yang digunakan dalam penelitian ini melalui observasi, wawancara dan dokumentasi. Observasi merupakan kegiatan mengamati langsung suatu objek. Teknik observasi dalam penelitian ini adalah melakukan kunjungan ke Kantor Kementerian Agama Kabupaten Gresik dan melakukan pengamatan secara langsung. Wawancara adalah proses memperoleh informasi mengenai tujuan penelitian dengan tanya jawab dan tatap muka antara pewawancara dan informan. Wawancara dilakukan dengan narasumber atau informan yaitu pranata Humas Kemenag Kabupaten Gresik. Dokumentasi merupakan teknik pengumpulan data dan penyimpanan data berupa tertulis,rekaman, dan tercetak. (Bungin, 2007)

Sedangkan teknik analisis data menggunakan analisis kualitatif dengan langkah pengumpulan data, reduksi data, penyajian data, dan penarikan kesimpulan.

- Pengumpulan Data (Data Collection)

Data-data yang diperoleh dari Kantor Kementerian Agama Kabupaten Gresik berasal dari narasumber dan hasil observasi, interview dan dokumentasi. Pencatatan dilakukan berdasarkan hasil wawancara, dibuat dengan bentuk catatan kecil. Catatan tersebut kemudian di deskripsikan menjadi sebuah narasi deskriptif dan jurnal reflektif atas fenomena yang terjadi dilapangan.

- Reduksi Data (Reduction) 
Reduksi data merupakan proses pemilihan, pemusatan perhatian pada penyederhanaan, pengabsrakan dan transformasi data kasar yang muncul dari catatan lapangan. Reduksi data merupakan wujud analisis yang menajamkan, mengklasifikasikan, mengarahkan, membuang data yang tidak berkaitan dengan aktivitas humas dalam mengelola layanan informasi melalui egovernment. Selanjutnya dibuat ringkasan, pengkodean, penelusuran tema-tema, membuat catatan kecil yang dirasakan penting pada kejadian. Pencatatan yang dilakukan hanya yang berkaitan dengan pelaksanaan humas dalam mengelola layanan informasi.

- Penyajian Data (Display)

Langkah sesudah mereduksi data adalah penyajian data. Teknik penyajian data dalam kualitatif adalah berupa uraian, bagan, hubungan antar katagori, dan sejenisnya. Pada tahap ini disajikan data hasil temuan dilapangan dalam bentuk teks naratif, yaitu uraian verbal tentang pelaksanaan humas dalam mengelola layanan informasi melalui e-government.

- Penarikan Kesimpulan dan Verifikasi

Dalam analisis data kualitatif memberi kesimpulan dan verifikasi. Demikian kesimpulan dalam penelitian kualitatif dapat menjawab rumusan masalah yang dirumuskan pada awal penelitian, namun juga terdapat kemungkinan tidak. Penarikan kesimpulan penelitian dapat dilihat proses pelaksanan humas dalam mengelola layanan informasi baik internal maupun eksternal lingkungan kantor.

\section{Hasil dan Pembahasan}

Dalam upaya meningkatkan partisipasi publik dapat dilakukan dengan berbagai cara salah satunya adalah dengan membangun komunikasi dua arah yang efektif dengan masyarakat melalui media. Media merupakan salah satu unsur dalam komunikasi, media memegang peranan penting dalam mensukseskan upaya humas. Setiap media memiliki keunggulan dan kelemahanya masing-masing, namun jika digunakan secara terpadu maka fungsi dari media-media tersebut akan saling melengkapi. Pelaksanaan penyiaran informasi kegiatan pemerintah di publikasikan melalui 
media komunikasi. Media komunikasi yang dipakai dalam penyiaran ini adalah media massa baik cetak maupun elektronik, serta media online. Penggunaan media informasi secara online dapat dimaksimalkan penggunaannya disesuaikan dengan karakteristik berita, pengguna dan tujuannya, sehingga berbagai media online tersebut saling melengkapi. Sejauh ini yang dilakukan oleh humas terkesan memberikan informasi pemerintahan yang seragam melalui berbagai media komunikasi tanpa dapat memberikan perbedaan tujuan dan fungsi yang menonjol di antara semua media komunikasi yang digunakan.

Menurut Cutlip, Center dan Broom menyatakan bahwa Humas (Public Relations) adalah fungsi manajemen yang menilai sikap publik, mengidentifikasikan kebijaksanaan dan tata cara seseorang atau organisasi demi kepentingan publik, serta merencanakan dan melakukan suatu program kegiatan untuk meraih pengertian dan dukungan publik (2020). "The Statement of Mexico" mendefinisikan Public Relations sebagai seni dan ilmu pengetahuan sosial untuk menganalisis kecenderungan, memprediksi konsekuensikonsekuensi, menasihati para pemimpin organisasi, dan melaksanakan program-program yang berencana mengenai kegiatan-kegiatan yang melayani baik kepentingan organisasi maupun kepentingan umum (2011) . Apabila disimpulkan maka Public Relations atau Hubungan Masyarakat merupakan bagian dari fungsi manajemen yang diperlukan dalam suatu organisasi atau lembaga untuk mendukung pencapaian visi dan misi lembaga tersebut, melalui serangkaian program yang direncanakan dan diimplementasikan kepada khalayak baik eksternal maupun internal lembaga, guna menciptakan pemahaman dan memperoleh timbal balik yang saling menguntungkan antar pihak.

Sesuai Peraturan Menteri Pendayagunaan Aparatur Negara dan Reformasi Birokrasi Republik Indonesia Nomor 6 Tahun 2014 pasal 4 Tugas pokok Pranata Humas adalah melakukan kegiatan pelayanan informasi dan kehumasan, meliputi perencanaan pelayanan informasi dan kehumasan, pelayanan informasi, hubungan kelembagaan, hubungan personil, dan pengembangan pelayanan informasi dan kehumasan. 
Dari seluruh media baik media massa cetak dan elektronik yang digunakan untuk penyebaran informasi, Humas Kemenag Gresik telah mencoba untuk menciptakan ruang publik sebagai tempat komunikasi yang dilakukan dalam wilayah sosial yang bebas dari sensor serta penyuntingan dan dominasi. Ini sejalan dengan pemikiran Habermas yang melihat dunia publik sebagai wilayah yang memungkinkan pembentukan opini publik tempat semua orang terlibat di dalamnya. Penggunaan media online untuk keperluan penyebaran informasi berjalan sesuai dengan tujuan egovernment yakni terciptanya hubungan secara elektronik antara pemerintah dan masyarakat sehingga masyarakat dapat mengakses berbagai informasi mengenai pemerintahan dan menunjang good government dan keterbukaan informasi.

Hasil wawancara dengan Pranata Humas Kementerian Agama Kabupaten Gresik, pengelolaan layanan informasi Kemenag Gresik menggunakan media cetak, media online dan offline. Adapun layanan informasi melalui media cetak yakni berupa brosur profil kemenag, alur pendaftaran haji dan lain sebagainya. Sedangkan untuk media online layanan informasinya melalui, facebook, instagram, twitter dan \#kemenaggresik, yang berisikan informasi kegiatan dan kebijakan serta pengumuman mengenai pemerintahan seperti kegiatan-kegiatan kepala kemanag dan kepala seksi kemenag. Selain melalui media online tersebut Kemenag Kabupaten Gresik juga menggunakan melalui website www.kemenaggresik.go.id akan tetapi untuk saat ini website Kemenag Gresik masih dalam perbaikan. Namun hal tersebut masih dapat teratasi dengan baik namun belum optimal. Adapun pelayanan secara offline melalui PTSP (Pelayanan Terpadu Satu Pintu) merupakan salah satu program pemerintah dalam rangka peningkatan pelayanan publik, memangkas birokrasi pelayanan perizinan dan non perizinan, sebagai upaya mencapai good governance atau kepemerintahan yang baik. Pelayanan Terpadu Satu Pintu (PTSP) Kantor Kementerian Agama Kabupaten Gresik dimaksudkan untuk memberikan pelayanan terhadap beberapa jenis pelayanan yang diselenggarakan secara terintegrasi dalam satu tempat dan dikontrol sistem pengendalian manajemen. Dengan 
tujuan untuk mendekatkan, meningkatkan pelayanan kepada masyarakat serta untuk memperpendek proses pelayanan guna mewujudkan pelayanan yang cepat, mudah, murah, transparan, pasti dan terjangkau dalam suatu pelayanan terpadu satu pintu. Dengan konsep tersebut, pengguna layanan cukup datang ke PTSP dan bertemu dengan petugas front office kemudian menunggu proses selanjutnya. Hal ini meminimalisir interaksi antara pengguna layanan dengan petugas dalam rangka terciptanya tata kelola pemerintahan yang baik dan bersih.

Kemajuan teknologi informasi memberikan manfaat yang besar untuk kemaslahatan masyarakat. Tentunya dalam dunia yang sudah mengglobal ini, kemajuan teknologi diperlukan dan dimanfaatkan dalam segala bidang. Salah satunya adalah bidang teknologi informasi sebagai pelayanan pemerintah kepada publik. Sistem manajemen pemerintahan selama ini merupakan sistem hirarki dimana kewenangan dan komando sektoral yang mengerucut dan panjang. Untuk memuaskan kebutuhan masyarakat yang semakin beraneka ragam di masa mendatang harus dikembangkan sistem manajemen modern dengan organisasi berjaringan sehingga dapat memperpendek lini pengambilan keputusan serta memperluas rentang kendali. Oleh karena itu dalam era otonomi daerah ini untuk mewujudkan pemerintahan yang good governance salah satu upayanya adalah menggunakan teknologi informasi dan komunikasi atau yang populer disebut Elektronic Government (E-Goverment) (Kusuma Habibie, 2019).

The World Bank mendefinisikan e-government sebagai berikut: "e-government refers to the use by government agencies of information technologies (such as Wide Area Network, the Internet, and mobile computing) that have the ability to transform relations with citizens, businesses, and other arms of government. Definisi lebih sederhana menurut UNDP (United Nation Development Program), "e-government is the application of Information and Communication Technology (ICT) by government agencies. Artinya bahwa pemeanfaatan teknologi informasi e-governmet oleh pemerintahan untuk membuka komunikasi, menjalin interaksi dan transaksi dengan masyarakat dan antar pemerintahan lainnya 
terkait pembangunan yang lebih baik. Konsep dasar dari penerapan e-government adalah bagaimana pemerintah mampu memberikan pelayanan publik melalui elektronik dengan memanfaatkan TIK seperti internet, perangkat genggam/smartphone, komputer dan sebagainya (Suciska, 2016).

Di Indonesia, penerapan e-government oleh Pemerintah Republik Indonesia diawali dengan diterbitkannya Instruksi Presiden Republik Indonesia Nomor 3 Tahun 2003 Tentang Kebijakan Dan Strategi Nasional Pengembangan e-government, diikuti dengan Panduan Penyusunan Rencana Induk Pengembangan e-government Lembaga dari Kementrian Kominfo RI. Adanya e-government diharapkan bisa memberikan beberapa manfaat, yakni:

- Memperbaiki kualitas pelayanan pemerintah kepada para stakeholder-nya (masyarakat, kalangan bisnis, dan industri) terutama dalam hal kinerja efektivitas dan efisiensi di berbagai bidang kehidupan bernegara;

- Meningkatkan transparansi, kontrol, dan akuntabilitas penyelenggaraan pemerintahan dalam rangka penerapan konsep Good Corporate Governance;

- Mengurangi secara signifikan total biaya administrasi, relasi, dan interaksi yang dikeluarkan pemerintah maupun stakeholdernya untuk keperluan aktivitas sehari- hari;

- Memberikan peluang bagi pemerintah untuk mendapatkan sumber-sumber pendapatan baru melalui interaksinya dengan pihak-pihak yang berkepentingan;

- Menciptakan suatu lingkungan masyarakat baru yang dapat secara cepat dan tepat menjawab berbagai permasalahan yang dihadapi sejalan dengan berbagai perubahan global dan trend yang ada;

- Memberdayakan masyarakat dan pihak-pihak lain sebagai mitra pemerintah dalam proses pengambilan berbagai kebijakan publik secara merata dan demokratis;

- Menciptakan masyarakat berbasis komunitas informasi yang lebih berkualitas (Suciska, 2016). 
Sebagai salah satu fasilitas layanan publik milik Kantor Kementrian Agama Kabupaten Gresik, Pelayanan Terpadu Satu Pintu (PTSP) selalu berupaya untuk meningkatkan performa pelayanan serta melakukan inovasi dalam rangka perbaikan dan optimalisasi layanan pada PTSP, diharapkan dapat melayani masyarakat dengan baik, dengan menggunakan prinsip-prinsip pelayanan publik yaitu keterpaduan, ekonomis, akuntabilitas, aksesibilitas, simplifikasi, kenyamanan, disiplin, sopan dan ramah. Adapun Penyelenggaraan PTSP di Kemenag Gresik, yaitu :

- Menyelenggarakan Pelayanan dengan Prinsip :

- 3 S (Salam, Senyum, Sapa)

- CERMAT (Cepat, Efektif, Ramah, Membantu, Amanah dan Tuntas)

- Memberikan Pelayanan secara Cerdas, Ikhlas dan Tuntas

- Berorientasi pada Standart Kepuasan Masyarakat (SKM)

- Berpegang Teguh pada Prosedur dan Peraturan Perundangundangan

- Menjunjung Tinggi Nilai-nilai Agama dan Norma Kesopanan Untuk dapat menjamin bahwa pelayanan yang diberikan PTSP bisa terlaksana dengan baik, penyelenggaraan layanan harus menyusun Standar Pelayanan. Standar pelayanan adalah tolak ukur yang dipergunakan sebagai pedoman penyelenggaraan pelayanan dan acuan penilaian kualitas pelayanan sebagai kewajiban dan janji penyelenggara kepada masyarakat dalam rangka pelayanan yang berkualitas, cepat, mudah, terjangkau, dan terukur.

\section{Kesimpulan}

Public Relations atau Hubungan Masyarakat merupakan bagian dari fungsi manajemen yang diperlukan dalam suatu organisasi atau lembaga, untuk mendukung pencapaian visi dan misi lembaga tersebut, melalui serangkaian program yang direncanakan dan diimplementasikan kepada khalayak baik eksternal maupun internal lembaga. Humas Kemenag Gresik telah mencoba untuk menciptakan ruang publik sebagai tempat komunikasi yang dilakukan dalam wilayah sosial bebas dari sensor serta penyuntingan dan dominasi. Sejalan dengan pemikiran Habermas 
yang melihat dunia publik sebagai wilayah yang memungkinkan pembentukan opini publik tempat semua orang terlibat di dalamnya. Penggunaan media online untuk keperluan penyebaran informasi berjalan sesuai dengan tujuan e-government yakni terciptanya hubungan secara elektronik antara pemerintah dan masyarakat sehingga masyarakat dapat mengakses berbagai informasi mengenai pemerintahan dan menunjang good government dan keterbukaan informasi.

Pengelolaan layanan informasi kemenag gresik menggunakan media cetak, media online dan offline. Adapun layanan informasi melalui media cetak yakni berupa brosur profil kemenag, alur pendaftaran haji dan lain sebagainya. Sedangkan untuk media online layanan informasinya melalui, facebook, instagram, twitter dan \#kemenaggresik. Selain melalui media online tersebut kemenag kabupaten gresik juga menggunakan website www.kemenaggresik.go.id namun masih dalam perbaikan. Sedangkan pelayanan offline kemenag gresik memiliki PTSP yaitu Pelayanan Terpadu Satu Pintu. Penyelenggaraan layanan publik Kementerian Agama Kabupaten Gresik baik offline maupun online telah sesuai dengan teori.

Untuk kedepannya Kemenag Kabupaten Gresik akan memaksimalkan sumber daya manusia yang ada, menambah inovasi dan kreatifitas pegawai dengan program one man one innovation kemudian akan memperbaiki sistem informasi manajemennya.

Untuk mempermudah dalam memberikan layanan di Kantor Kementerian Agama Kabupaten Gresik seharusnya segera memperbaiki website sehingga masyarakat dapat mengakses dengan mudah melalui website mengenai program dan kegiatan Kantor Kementerian Agama Kabupaten Gresik. Selain itu sejalan dengan perkembangan teknologi dan informasi segala aspek informasi baik pelayanan maupun publikasi dilakukan melalui media sosial. Untuk mempermudah pelaksanaan pelayanan sebaiknya menggunakan aplikasi pada seiap seksi terutama pada persuratan baik untuk surat masuk maupun surat keluar agar dokumen tidak hilang dan tersimpan dengan rapi. Dengan 
Dalilah Ayu Permatasari, Irsyadatun Ni'mah Almatin, Wiladatus Sholihah, Ali Mustofa,

demikian layanan informasi dapat tersampaikan secara efektif dan efisien.

\section{References}

(2011). Diambilkembalidari

https://komunikasimanajemen.wordpress.com/2011/01/20/pu blic-relations-2/

(2020, Juli). Diambilkembalidari https://id.wikipedia.org/wiki/Daftar_definisi_hubungan_mas yarakat

Bungin, B. (2007). Penelitian Kualitatif: Komunikasi, Ekonom, Kebijakan Publik. Jakarta: Kencana.

Diah Anggrahini, M., Rochayanti, C., \& Arif Sosiawan, E. (2008, mei). Peran Humas Pemerintah Kabupaten Sragen Dalam Pengelolaan Isi Informasi Website Pemda Sebagai Media Comunication Relation Dengan Masyarakat. Jural Ilmu Komunikasi, 6, 148.

Elysia, V., Wihadanto, A., \& Sumartono. (t.thn.). Implementasi EGovernment Untuk endorong Pelayanan Publik Yang Terintegritas di Indonesi. Optimalisasi Peran Sans dan Teknologi Untuk Mewujudkan Smart City, 354.

J. Moleong, L. (2008). Metodologi Penelitian Kualitatif. Bandung: PT Remaja Rosda Karya.

Kusuma Habibie, D. (2019, Maret). Citizen-Centric E-Govermrnt Pelayanan Publik. Jurnal KebijakanPublik, 10.

Purworini, D., \& Purworini, D. (2014, Maret). Model Informasi Publik di Era Media Sosial : KajianGrounded Teori di Pemda Sukoharjo. Model Informasi Publik di Era Media Sosial, 4, 4.

Rakhmat, J. (2012). Metode Penelitian Komunikasi. Bandung: PT Remaja Rosdakarya. Suciska, W. (2016). Optimalisasi Penerapan E-Government Melalui Media Sosial Da;lam

Mewujudkan Good Governmace. Prosiding Seminar Nasional Komunikasi. 